\title{
Critical limits of the soil physical properties for cotton
}

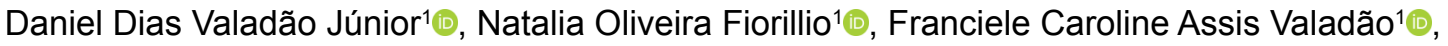 \\ Paulo Rogério Guimarães ${ }^{1} \oplus$, Cláudia Magalhães Souza Targino ${ }^{1} \oplus$, José Luiz Silva ${ }^{1} \oplus$, Flavio Carlos Dalchiavon ${ }^{1}$

\footnotetext{
${ }^{1}$ Instituto Federal de Educação, Ciência e Tecnologia de Mato Grosso, Campo Novo do Parecis-MT, Brasil. E-mail: daniel.valadao@cnp.ifmt.edu.br; nofiorillio@hotmail.com; franciele.valadao@cnp.ifmt.edu.br; paulorogerio_juina@hotmail.com; claudiamagso@hotmail.com; jose.silva@cnp.ifmt.edu.br; flavio.dalchiavon@cnp.ifmt.edu.br
}

ABSTRACT: The objective of this study was to establish the relation between the soil physical properties and the cotton crop development in order to determine the critical limits. For this, an experiment was performed in a randomized block design in a dystrophic Red Oxisol typical of a clayey texture. The treatments consisted of five compaction states as a function of the different passages numbers of an agricultural tractor, with $\mathrm{C} 0$ : no additional traffic; $\mathrm{C} 1$ : one tractor passage; $\mathrm{C} 2$ : three tractor passages; C3: six tractor passages and C4: eleven tractor passages. The soil physical properties, root distribution in its layers, vegetative and reproductive characteristics, and root anatomy were all evaluated. Cotton crop has been shown to be sensitive to compacted soils. Compaction promoted the arrangement of the soil solid particles, and it was possible to establish that the productivity is reduced with values of $0.26 \mathrm{~m}^{3} \mathrm{~m}^{-3}, 0.27 \mathrm{~m}^{3} \mathrm{~m}^{-3}$ and $0.90 \mathrm{MPa}$ of macroporosity, microporosity and soil resistance to penetration, respectively. Soil compaction causes changes in the root system, with a reduction in the explored volume and increased root diameter, reflecting a yield drop.

Key words: Gossypium hirsutum; root development; soil compaction

\section{Limites críticos de propriedades físicas do solo para o algodão}

RESUMO: O objetivo deste trabalho foi estabelecer a relação das propriedades físicas do solo e o desenvolvimento da cultura do algodoeiro para determinar os limites críticos. Para isso, foi implantado um experimento em delineamento de blocos ao acaso em um Latossolo Vermelho distrófico típico de textura argilosa. Os tratamentos consistiram de cinco estados de compactação em função de diferentes números de passadas de um trator agrícola, sendo: C0: sem trafego adicional; C1: uma passada de trator; $\mathrm{C}$ : três passadas de trator; $\mathrm{C}$ : seis passadas de trator e C4: onze passadas de trator. Foram avaliadas as propriedades físicas do solo, distribuição das raízes nas camadas, características vegetativas, reprodutivas e a anatomia das raízes. $\mathrm{O}$ algodão demostrou ser uma cultura sensível a solos compactados. A compactação promoveu 0 arranjo das partículas sólidas do solo, sendo possível estabelecer que a produtividade é reduzida com valores $0,26 \mathrm{~m}^{3} \mathrm{~m}^{-3}, 0,27 \mathrm{~m}^{3} \mathrm{~m}^{-3}$ e $0,90 \mathrm{MPa}$ de macroporosidade, microporosidade e resistência do solo a penetração, respectivamente. A compactação do solo provoca alterações no sistema radicular, com diminuição do volume explorado e aumento do diâmetro radicular, refletindo em queda na produtividade.

Palavras-chave: Gossypium hirsutum; desenvolvimento radicular; compactação de solo 


\section{Introduction}

In cotton cultivation areas, mandatory destruction of stalks is adopted for the preventive control of the boll weevil (Anthonomus grandis) and the predominant soil tillage system is the conventional one, with the use of a plow harrow. This routine causes interference in the soil structure, and compaction may occur.

Compaction can be defined as a process that leads to a decrease in the soil volume by adding an external pressure, which can be caused by the traffic of agricultural machinery and equipment or the transit of animals (Lima, 2004). The depth that compaction will propagate depends on the mass and pressure applied on the soil surface. In the case of agricultural machinery tires, they have a larger contact area for sharing the weight, thus generating less pressure; however, the soil deformation forces propagate to greater depths (Pellegrini et al., 2016).

Continuous use of machinery increases the chances of soil compaction, especially in the clayey ones, by forming an obstacle to root development, originated from the compression of unsaturated soil, with it as the main cause of physical degradation of agricultural soils (Stefanoski et al., 2013). In compacted soils, there is an increase in density, resistance to penetration of roots and in microporosity, which in turn contributes to the reduction of macroporosity (Beutler et al., 2005).

Valadão et al. (2015) found that the compaction limits the soil volume that is explored by the root system, which normally strengthen the compaction effects with water deficit and impairment of the nutrients absorption, especially those dependent on diffusion, such as phosphorus, potassium and zinc (Malavolta, 2006). It's noteworthy to emphasize that cotton still presents more problems, as it is grown in the region as second crop and long cycle, thus subjected to low rainfall.

In the literature, it is possible to find authors who try relating the soil physical properties with root growth in search of critical values. Miguel et al. (2007) observed that macroporosity values greater than $0.10 \mathrm{~m}^{3} \mathrm{~m}^{-3}$ is the minimum for liquid and gaseous exchanges between the external environment and soil, and it is critical for the roots growth of most crops; therefore, it must be considered that in dry soil the resistance to penetration can be lesser than $1 \mathrm{MPa}$, and in soils with enough moisture the roots can grow with the resistance between 4 and $5 \mathrm{MPa}$ (Rossetti \& Centurion, 2017). Pacheco et al. (2015) concluded that the soil density from $1.4 \mathrm{Mg} \mathrm{m}^{-3}$ onwards is already reducing the growth of aerial part and root of crotalaria. Under the same soil conditions as this study, Scapinelli et al. (2016) found that values above $0.733 \mathrm{MPa}$ of soil resistance to penetration reduced sunflower productivity, whereas values below $0.264 \mathrm{~m}^{3} \mathrm{~m}^{-3}$ of soil macroporosity reduced the root area index, trait considered as critical for the crop.

Evaluation of isolate factors is insufficient for obtaining conclusive information, which requires the search for alternatives. lijima et al. (2007) subjected the roots of corn, rice, peas, and cotton to conditions of soil physical stress due to drought, anaerobiosis and mechanical impedance, concluding that cotton is the species that shows the greatest roots development in compacted soil condition. Scapinelli et al. (2016) concluded that soil compaction promotes aerenchyma formation in the sunflower roots, this being typical of soil with oxygen restriction, caused in this case by the soil compaction.

In this context, the objective was to quantify the effect of compaction on root growth and anatomy, vegetative and reproductive attributes of the cotton crop, seeking to determine critical indexes of the soil physical properties.

\section{Materials and Methods}

The research was implemented in the experimental area from the Federal Institute of Education, Science and Technology of Mato Grosso, Campo Novo do Parecis Campus, located at $13^{\circ} 40^{\prime} 41^{\prime \prime}$ latitude $S$ and $57^{\circ} 47^{\prime} 25^{\prime \prime}$ longitude $O$, with altitude of $561 \mathrm{~m}$. The region climate is Aw according to the Köppen classification (Ferreira, 2001), and the precipitation and rainfall data for the period are displayed in Figure 1. The area soil was a typical Dystrophic Red Latosol (Oxisol), according to the principles of the Brazilian System of Soil Classification (Santos et al., 2018). Chemical characteristics and texture of the soil, in the layer from 0.00 to $0.20 \mathrm{~m}$, are displayed in Table 1 .

The design adopted was randomized blocks, with five treatments and five replicates, totaling 25 plots. Treatments consisted of five compaction states as a function to the

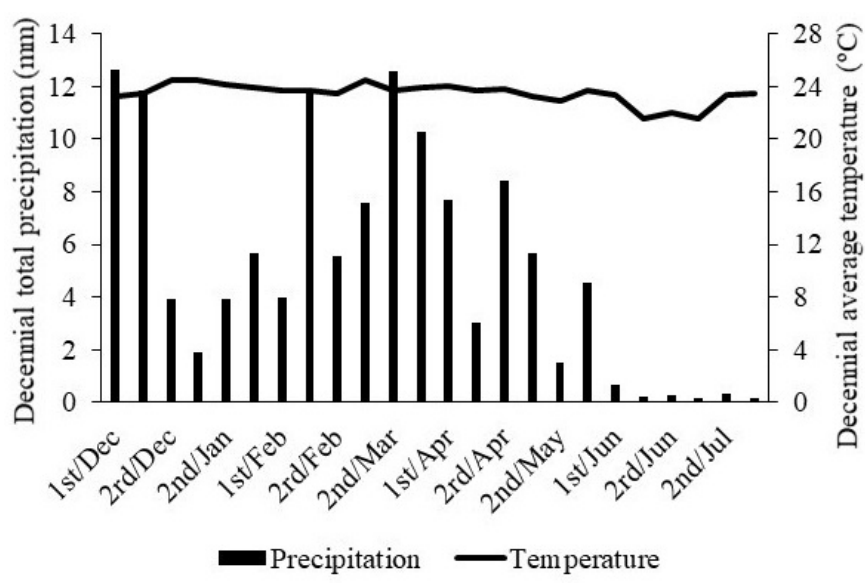

Figure 1. Precipitation and mean air temperature, decennials, in the research area, from December/2014 to July/2015. First, second and third $=$ decennial of each month.

Table 1. Chemical and textural characteristics of the soil in the experimental area at the implementation of the study.

\begin{tabular}{|c|c|c|c|c|c|c|c|c|c|c|}
\hline \multirow{2}{*}{$\underset{\mathrm{CaCl}_{2}}{\mathrm{pH}}$} & $\mathbf{P}$ & K & $\mathrm{Ca}$ & $\mathrm{Mg}$ & Al & $\mathbf{H}$ & MO & Clay & Silt & Sand \\
\hline & \multicolumn{2}{|c|}{$\left(\mathrm{mg} \mathrm{dm}^{-3}\right)$} & \multicolumn{4}{|c|}{$\left(\mathrm{cmol}_{\mathrm{c}} \mathrm{dm}^{-3}\right)$} & \multicolumn{4}{|c|}{$\left(\mathrm{g} \mathrm{kg}^{-1}\right)$} \\
\hline 5.50 & 9.20 & 45.40 & 3.00 & 1.08 & 0.00 & 2.92 & 30.4 & 506 & 134 & 360 \\
\hline
\end{tabular}


different numbers of passages of an agricultural tractor, with C0: no additional traffic; $\mathrm{C} 1$ : one tractor passage; $\mathrm{C2}$ : three tractor passages; $\mathrm{C} 4$ : six tractor passages and $\mathrm{C} 5$ : eleven tractor passages.

The plots were $8 \mathrm{~m}$ long and $3.6 \mathrm{~m}$ wide, making up a total area of $28.8 \mathrm{~m}^{2}$. Soil compaction was induced after the first rains of the 2014/2015 agricultural crop. The agricultural tractor used was the MF 292 (105 hp), with diagonal tire wheels, $1.7 \mathrm{~m}$ rear gauge and a total weight of $5.1 \mathrm{Mg}$ with $95 \mathrm{kPa}$ inflation pressure on the front tires (14.9-24 R1) and $110 \mathrm{kPa}$ at the rear ones (19.4-34 R1), with $42 \%$ of the weight distributed on the front axle and $58 \%$ on the rear axle. Aiming increasing the weight, to guarantee compaction levels, an additional $1.0 \mathrm{Mg}$ was added to this tractor by means of two concrete beams coupled at the front and two at the rear, which corresponded to more $6.0 \mathrm{Mg}$ of weight on the soil by tractor. During tractor traffic, the second gear was use, reduced to a 1,600 rpm rotation and an average speed of 5.2 $\mathrm{km} \mathrm{h}^{-1}$. After implementing the compaction, the millet sowing was held as a cover plant, aiming at the straw production to protect the soil in the rainy season. In early January 2015, the cotton was dried and mechanically sown. The spacing used was $0.45 \mathrm{~m}$ between rows and 12 seeds $\mathrm{m}^{-1}$ at a sowing depth of $0.03 \mathrm{~m}$. Control of invasive plants, pests and diseases was performed according should the need arises, verified through periodic monitoring of the crops, always aiming to eliminate external interference of any kind to the treatments (Table 2).

The four depths considered for soil physical properties and the root system were: from 0.0 to $0.05 \mathrm{~m}$; from 0.05 to 0.10 $\mathrm{m}$; from 0.10 to $0.15 \mathrm{~m}$ and from 0.15 to $0.20 \mathrm{~m}$. In the cotton full flowering period, soil samples were collected by using an extractor ring $0.04 \mathrm{~m}$ long and with $0.05 \mathrm{~m}$ in diameter, pushed vertically into the soil thought a sampler. In these samples, the following physical properties were evaluated: soil density, total porosity, macro and microporosity, all according to Teixeira et al. (2017).

Soil resistance to penetration was performed by using an automatic electronic penetrograph. In this evaluation, the mean of the plot was obtained through three surveys up to a $0.20 \mathrm{~m}$ depth. At the same moment of penetrometry, a deformed sample was also collected in order to determine the soil water content.

- $\quad$ Stem diameter: at 140 days after emergence (DAE), determined with a digital caliper on 10 plants per plot, 0.05 $\mathrm{m}$ from the soil;
- Number of green bolls: at $130 \mathrm{DAE}$, by counting the total in 10 plants per plot;

- Number of bolls: at $170 \mathrm{DAE}$, by counting in 10 plants per plot;

- Weight of bolls: at $180 \mathrm{DAE}$, by collecting 10 bolls per plot;

- Yield: at $180 \mathrm{DAE}$, the harvest was carried out manually at $20 \mathrm{~m}$ per plot. For this purpose, two external lines and two meters at each end of the five central lines were disregarded. Then, the plume was weighed with seeds to determine yield per hectare (@ ha ${ }^{-1}$ ).

Results were submitted to the analysis of variance and, when $F$ was significant $(p<0.05)$, regression was applied to the compaction ranges by using the Sisvar statistical program (Ferreira, 2011). Moreover, aiming to determine the critical indexes, a correlation analysis was performed between the soil physical properties with the root diameter and seed cotton yield.

\section{Results and Discussion}

Soil physical properties (macroporosity, microporosity, total porosity, density and soil resistance to penetration [SRP]) regardless of the depth were all altered by additional tractor traffic. Soil moisture collected at the time of the SRP evaluation was not influenced by compaction, having $0.25 \mathrm{~g} \mathrm{~g}^{-1}$ as its mean.

Macropores (Figure 2A) were reduced with the increasing external pressure, with an $54.2 \%$ mean reduction of the pores at all depths when in comparison to the treatment with no additional passage in relation to the treatment with 11 additional passages, reaching $0.11 \mathrm{~m}^{3} \mathrm{~m}^{-3}$ of macropores and becoming more accentuated as the depth decreases. These results are similar to those found by Gomes et al. (2015), who showed that the highest porosity values were observed in the 0.2-0.4 m depth layer, indicating the compaction of the first soil layers in the profile. Porosity reductions, mainly of macroporosity, affect several soil attributes such as hydraulic conductivity, soil permeability and water infiltration (Pellegrini et al., 2016), which in turn limits plant growth and development as it affects the root survival medium. This reduction is even more harmful if the reduction in precipitation that occurred in the months of May and June is observed, when the water availability in the soil for the cotton is still lacking.

One of the consequences from the macropores reduction is the micropores formation (Andreola et al., 2000) (Figure 2B),

Table 2. Pesticides applied in culture to control diseases, insect pests and invasive plants.

\begin{tabular}{|c|c|c|c|}
\hline Products & Active Ingredient & Dosage ha ${ }^{-1}$ & Application period* \\
\hline Herbicide & GLYPHOSATE+IMAZETHAPYR & $3 \mathrm{Lha}^{-1}$ & Pre-planting \\
\hline Herbicide & GLYPHOSATE & $3 \mathrm{Lha}^{-1}$ & $\mathrm{C} 1$ \\
\hline Insecticide & ACETAMIPRID+ACEPHATE & $100 \mathrm{~g} \mathrm{ha}^{-1}$ & V5-B5-C1 \\
\hline Insecticide & BETA-CYFLUTHRIN & $200 \mathrm{~mL} \mathrm{ha}^{-1}$ & B1-B5-F6-C1 \\
\hline Fungicide & DIFENOCONAZOLE & $0.5 \mathrm{Lha}^{-1}$ & V5-B1-B5-F6-C1 \\
\hline
\end{tabular}

${ }^{*} \mathrm{Vn}=$ vegetative stage; $\mathrm{Bn}=$ floral bud; $\mathrm{Fn}=$ flower opening phase; $\mathrm{Cn}=$ boll phase. All applications of insecticides and fungicides were held in batteries, that is, five consecutive applications with a three-day interval for each application. 

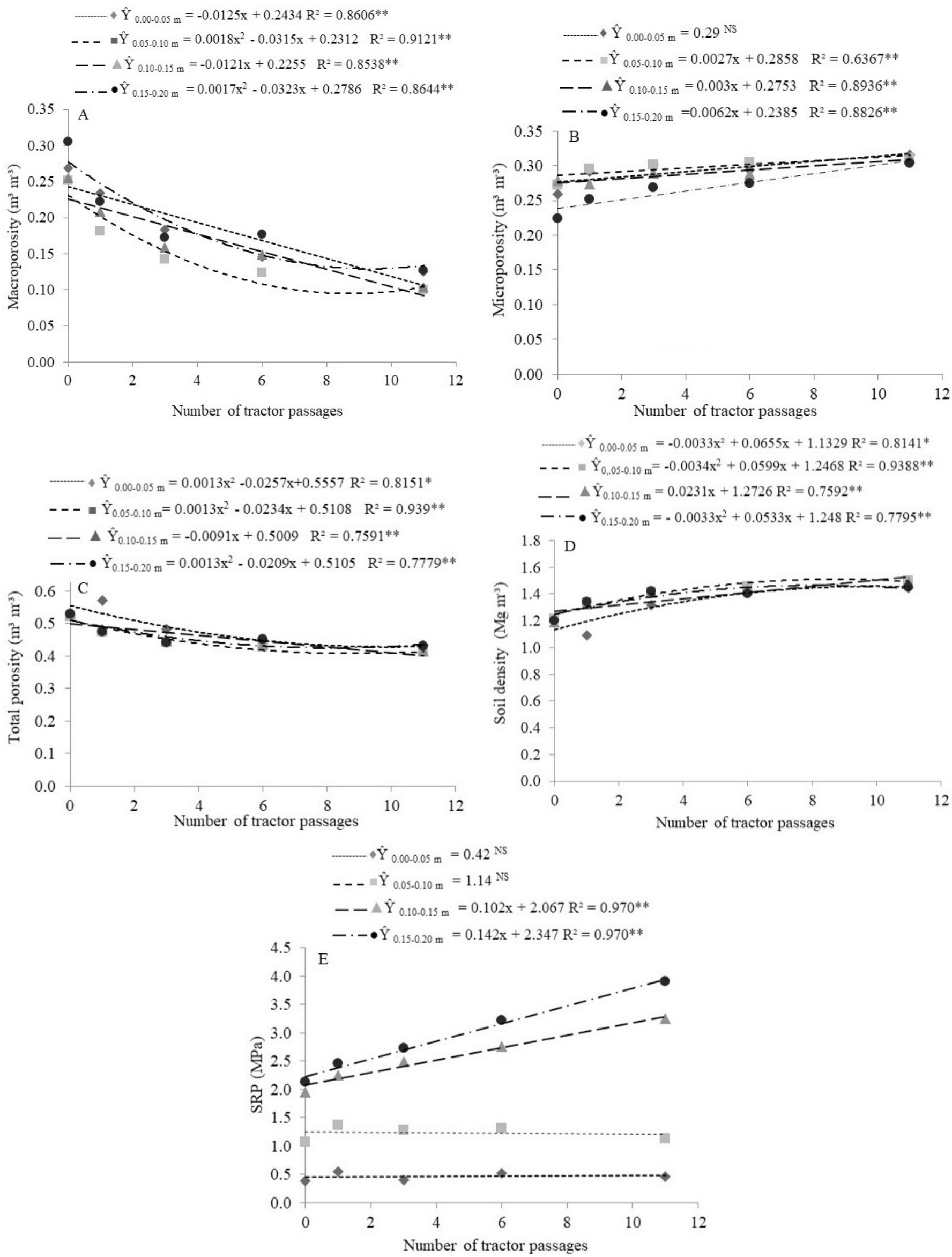

$\mathrm{SRP}=$ Soil Resistance to Penetration, ${ }^{*}$ significant by the $\mathrm{F}$ test $(\mathrm{p}<0.05),{ }^{* *}$ significant by the $\mathrm{F}$ test $(\mathrm{p}<0.01)$.

Figure 2. Soil physical properties in the different depth layers, depending on the soil compaction in the cotton crop. 
which was specially increased in the deeper layers, reaching up to $0.31 \mathrm{~m}^{3} \mathrm{~m}^{-3}$ at the highest level of induction. This increase occurs by the rearrangement of particles through the external pressure, when some macropores are occupied by smaller particles and form micropores in empty spaces. From a management point of view, these formed micropores are responsible for water retention, and so the aerated spaces reduce, leading to a lack of oxygen and other gases, thus reducing the volume of soil explored by the root system.

Since there is a direct relation between total porosity and the volume of macro and micropores, it decreased the rising additional traffic by $0.10 \mathrm{~m}^{3} \mathrm{~m}^{-3}$ (Figure $2 \mathrm{C}$ ), in all layers, reaching up to $0.42 \mathrm{~m}^{3} \mathrm{~m}^{-3}$ in the treatment with a higher degree of compaction. Gomes et al. (2015) reported in a pasture study that those two are inversely proportional and Ferreira et al. (2010) demonstrated that the critical density values were close to $1.40 \mathrm{Mg} \mathrm{m}^{-3}$, depending on the soil texture. Under the experiment conditions, the density had a gradual increase in the four depths, with the highest one verified in the layer from 0.10 to $0.15 \mathrm{~m}$, in which, with 11 additional passages, it reached $1.47 \mathrm{Mg} \mathrm{m}^{-3}$ (Figure 2D).

In the relation between the reduction of total porosity and the density increase, the factor that tries to represent the plant root system is formed, which is the soil resistance to penetration (SRP). In the present study (Figure 2E) it was not significantly changed until the $0.10 \mathrm{~m}$ depth; however, at the depths of $0.10-0.15$ and $0.15-0.20 \mathrm{~m}$ there was an increase reaching an SRP up of $1.98 \mathrm{MPa}$, demonstrating that, from $0.10 \mathrm{~m}$ on, the root system would have difficulties in penetrating. Valadão et al. (2015) found similar results, demonstrating that intensive traffic of machines on the soil increased its density and resistance to penetration, reflecting negatively in its macroporosity and total porosity. The lack of response in the first layers is probably due to the greater oscillation of temperature and humidity, the greater presence of roots and organic matter and the shear effect of the tractor tire at the time of the compaction induction.

The natural condition of the soil, or in other words, with no additional traffic, was: $1.19 \mathrm{Mg} \mathrm{m}^{-3}, 0.26 \mathrm{~m}^{3} \mathrm{~m}^{-3}, 0.26 \mathrm{~m}^{3}$ $\mathrm{m}^{-3}, 0.52 \mathrm{~m}^{3} \mathrm{~m}^{-3}$ and $0.60 \mathrm{Mpa}$, of density, macroporosity, microporosity, total porosity and SRP, respectively. On the other hand, in the conditions of a greater traffic, considering the same previous order, they were: $1.47 \mathrm{Mg} \mathrm{m}^{-3}, 0.11 \mathrm{~m}^{3} \mathrm{~m}^{-3}$, $0.31 \mathrm{~m}^{3} \mathrm{~m}^{-3}, 0.42 \mathrm{~m}^{3} \mathrm{~m}^{-3}$ and $1.98 \mathrm{MPa}$ (values obtained not considering the sampling depth). With the changes in the profile, the relationships modification draws attention, such as that of macropores:micropores, which dropped from 1:1 to 0.35 , thus changing the water dynamics and the chance of root growth in the soil. In spite of what is considered a physically ideal soil, that is, with approximately $50 \%$ porous space, the discrepancy between the two soil situations is evident. This characteristic, in turn, is similar to the density results obtained by Valadão et al. (2015) and Scapinelli et al. (2016), both performed on the same soil. As emphasized by Scapinelli et al. (2016), these changes come from intrinsic characteristics of the soil worked with, such as the plasticity, humidity, the tractor used, type of tire and the inflation pressure, which directly interfere in the soil volume that reduces and the soil mass that increases in a given occupied zone.

When compaction is present, root growth in the soil can only occur in fractures or biopores with less resistance to growth (Bengough et al., 2011), and the best way to observe the cotton root growth was visually (Figure 3).

When comparing the roots of the area with no additional traffic (Figure $3 A$ ) with the ones from areas with additional traffic (Figures $3 \mathrm{~B}$ to $3 \mathrm{E}$ ), reduction of secondary roots and the main root growth deviation is verified. In other words, even the smallest numbers of passages caused changes; however, when observing the traffic of six and eleven passages, the root system deformation is accentuated (Figures 3D and 3E). This fact indicates that the visual analysis of the root system remains as a good indicator of the compaction situation.

Though statistical analyzes of the root diameter, an increase in the first depths was observed, with it not being significant in the depth from 0.10 to $0.20 \mathrm{~m}$. This change (Figure 4) resulted in an increase in the root diameter from $1.74 \mathrm{~mm}$ to $2.95 \mathrm{~mm}$ in the $0.00-0.05 \mathrm{~m}$ layer, and from $0.27 \mathrm{~mm}$ to $1.76 \mathrm{~mm}$ in the $0.05-0.10 \mathrm{~m}$ layer, when comparing the treatment without induction with the one with greater induction, which occurred because the plant did not cross the barrier and tried to break it in some way, as an exhaust system. Müller et al. (2011) demonstrated, when working with green manure plants, that the increase in soil density caused an increase in the mean root diameter in the compacted layer.

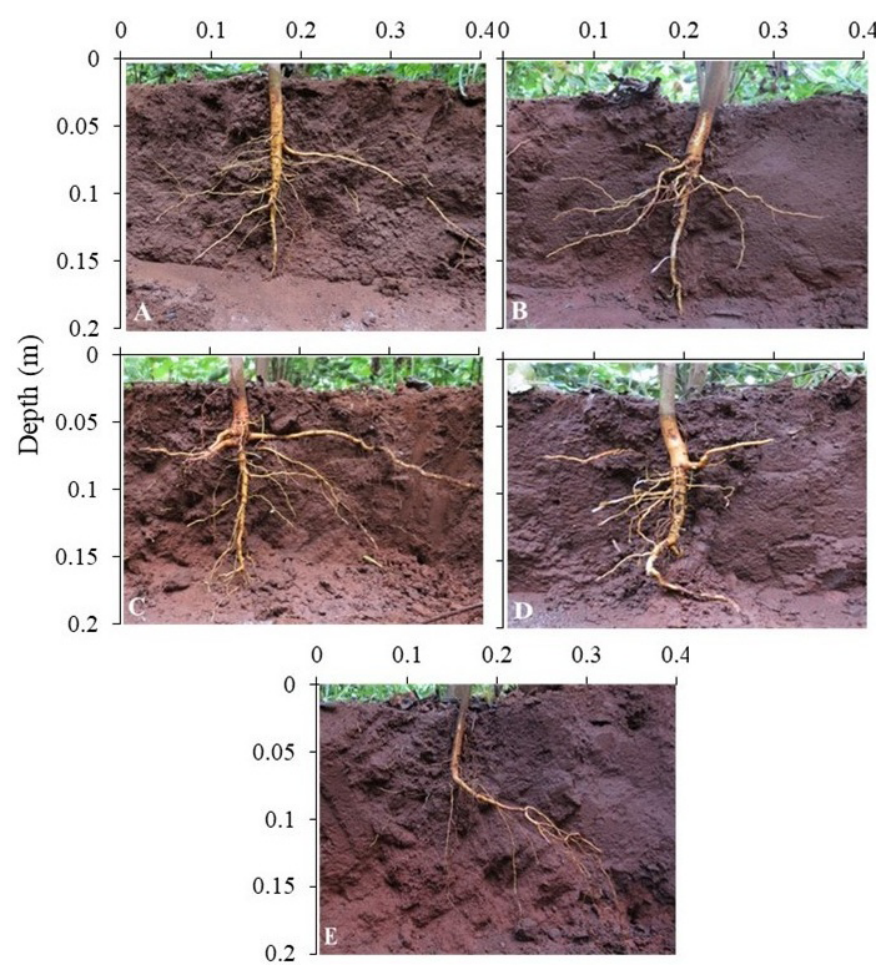

Figure 3. Exposure of the roots in cross section to the crop row and close to the plant axis. (A) no additional traffic; (B) one tractor passage; (C) three tractor passages; (D) six tractor passages; (E) eleven tractor passages. 


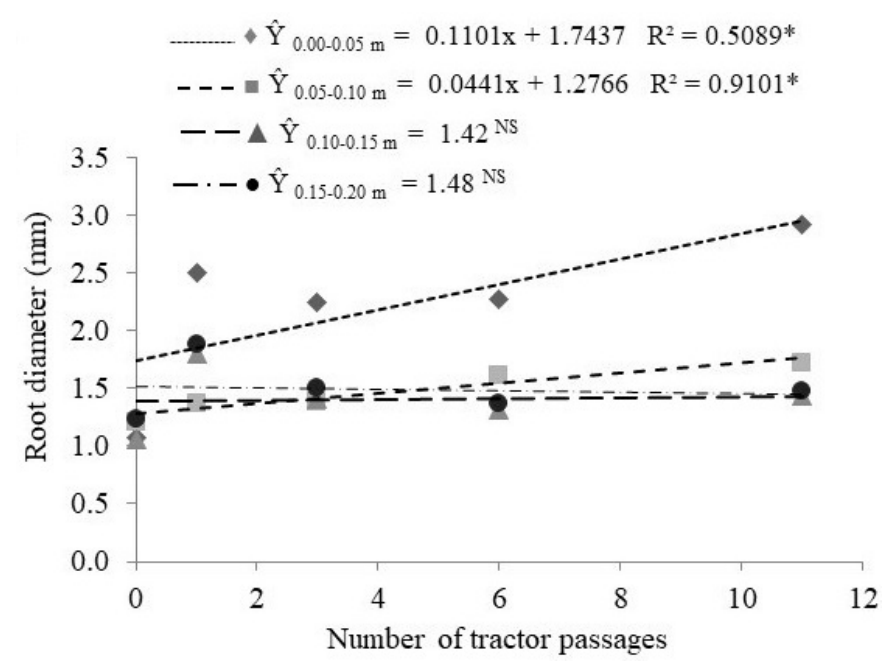

* Significant by the $\mathrm{F}$ test $(\mathrm{p}<0.05)$.

Figure 4. Mean root diameter of the roots located from 0.00 to $0.05 \mathrm{~m}$ and from 0.05 to $0.10 \mathrm{~m}$, depending on the number of tractor passages.

The high sensitivity of cotton plants to compaction makes them vulnerable to soil moisture conditions because its root system is unable to develop and then concentrates in a more superficial way. Another fact that should be noted is that, even if there is no change in the roots number, with the present roots thickening, there is lesser efficiency in the absorption of water and nutrients. Absence of change in root diameter in the $0.10-0.20 \mathrm{~m}$ layer may be linked to the low number of present roots, making the test unable to detect differences.

In the vegetative and yield variables, it was possible to observe what happened in the soil physical properties and its reflections in the root system. The plant collar diameter (Figure 5) had a linear reduction according to the compaction degree increase, reaching up to $11.7 \mathrm{~mm}$ in the highest degree of induction, whereas in the area without interference it was $15.25 \mathrm{~mm}$. Pessoa et al. (2015) reported that the same occurred with cowpea in the midst of stress due to compaction, which has a negative influence on the plant structure. Rossetti \& Centurion (2017) found that plants in soil

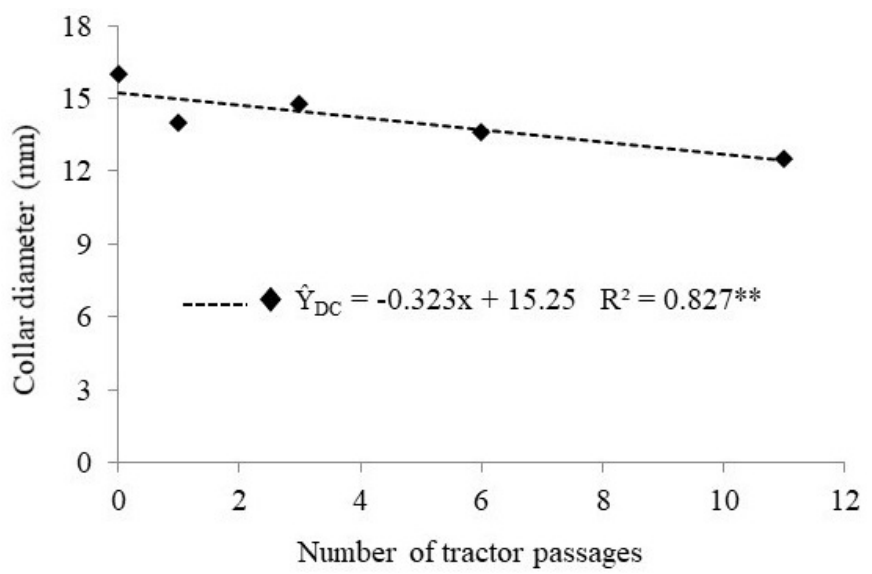

** Significant by the $\mathrm{F}$ test $(\mathrm{p}<0.01)$.

Figure 5. Collar diameter (DC) of the cotton plant, depending on the number of tractor passages. with SRP above $2 \mathrm{MPa}$ from $0.15 \mathrm{~m}$ in depth onwards have a reduction in the development of their structures in relation to the root system. Pellegrini et al. (2016) reported that the aerial part had a significant decrease based on the results of reducing stem and root diameter. Soil compaction resulting from increased machine traffic in agricultural activities can be a limiting factor for plant growth (Rossetti \& Centurion, 2017), thus the changes in the soil and consequently in the root system of the cotton plant have shown influence on its structure.

In addition to reducing stem diameter, a decrease in the number of green bolls and bolls is verified (Figure 6). The green bolls number in the treatment with a higher degree of compaction decreased by $39.8 \%$ when compared to the treatment without additional traffic. Formed bolls had a decrease of $35.15 \%$ at the time of this comparison was made. Regarding the weight of ten bolls, there was no difference between treatments (Mean $=0.063 \mathrm{~kg}$ ) Ns. These changes occurred due to the stressed plant having metabolic spends in order to break the soil barrier and develop, hence causing less investment in reproductive structures. In addition, nutritional restrictions can occur, such as a reduction in the levels of $\mathrm{N}$, $\mathrm{P}, \mathrm{Ca}$ and $\mathrm{Mg}$ absorbed by the plant by both the dynamics of nutrients and the lesser soil exploitation by the root system (Valadão et al., 2017).

As for yield, measured from the seed cotton, the higher the degree of compaction was, the lower the yield would be (Figure 7). Comparing the treatment with no additional traffic in which the mean yield was $254.6 \mathrm{Qha}^{-1}$, with the treatment of eleven tractor passages, with mean yield of 156.1 @ ha- ${ }^{-1}$, there was a reduction of $98.5 @$ ha $^{-1}$, or in other words, approximately $39 \%$ of yield.

Soil physical properties that showed correlation with the root diameter were macroporosity $(-0.737)$, microporosity (0.748) and SRP (0.761) (Figure 8). For yield, there was a correlation with macroporosity (0.947), microporosity $(-0.956)$, total porosity $(0.928)$, soil density $(-0.918)$ and SRP $(-0.875)$ (Figure 9). All significant at $p<0.01$.

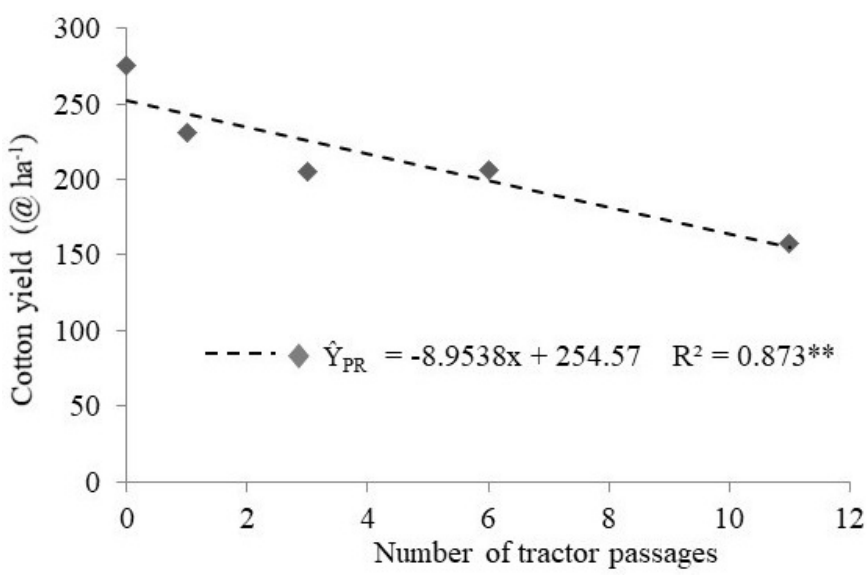

** Significant by the $\mathrm{F}$ test $(\mathrm{p}<0.01)$.

Figure 6. Number of green bolls (MA) and number of bolls (CA) as a function of the number of tractor passages. 


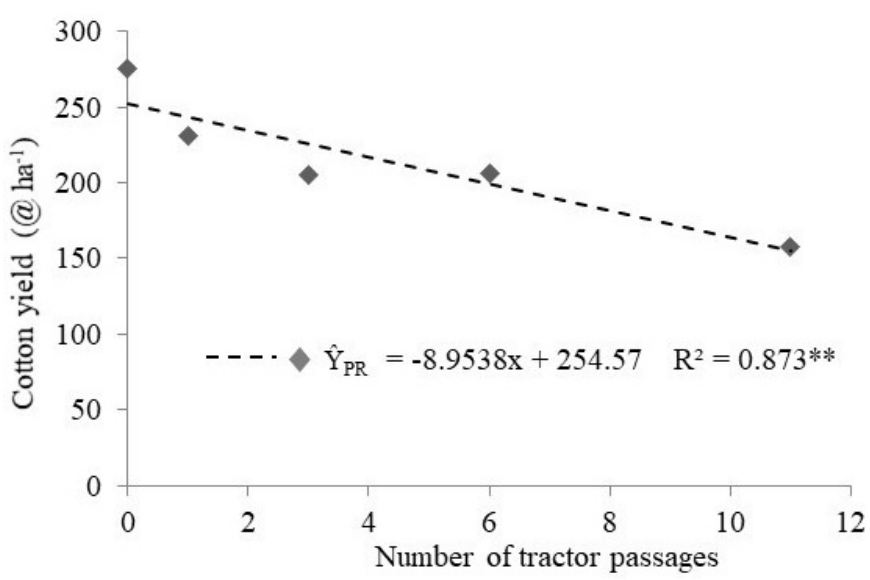

** Significant by the $\mathrm{F}$ test $(\mathrm{p}<0.01)$.

Figure 7. Cotton yield (PR) as a function of the number of tractor passages.
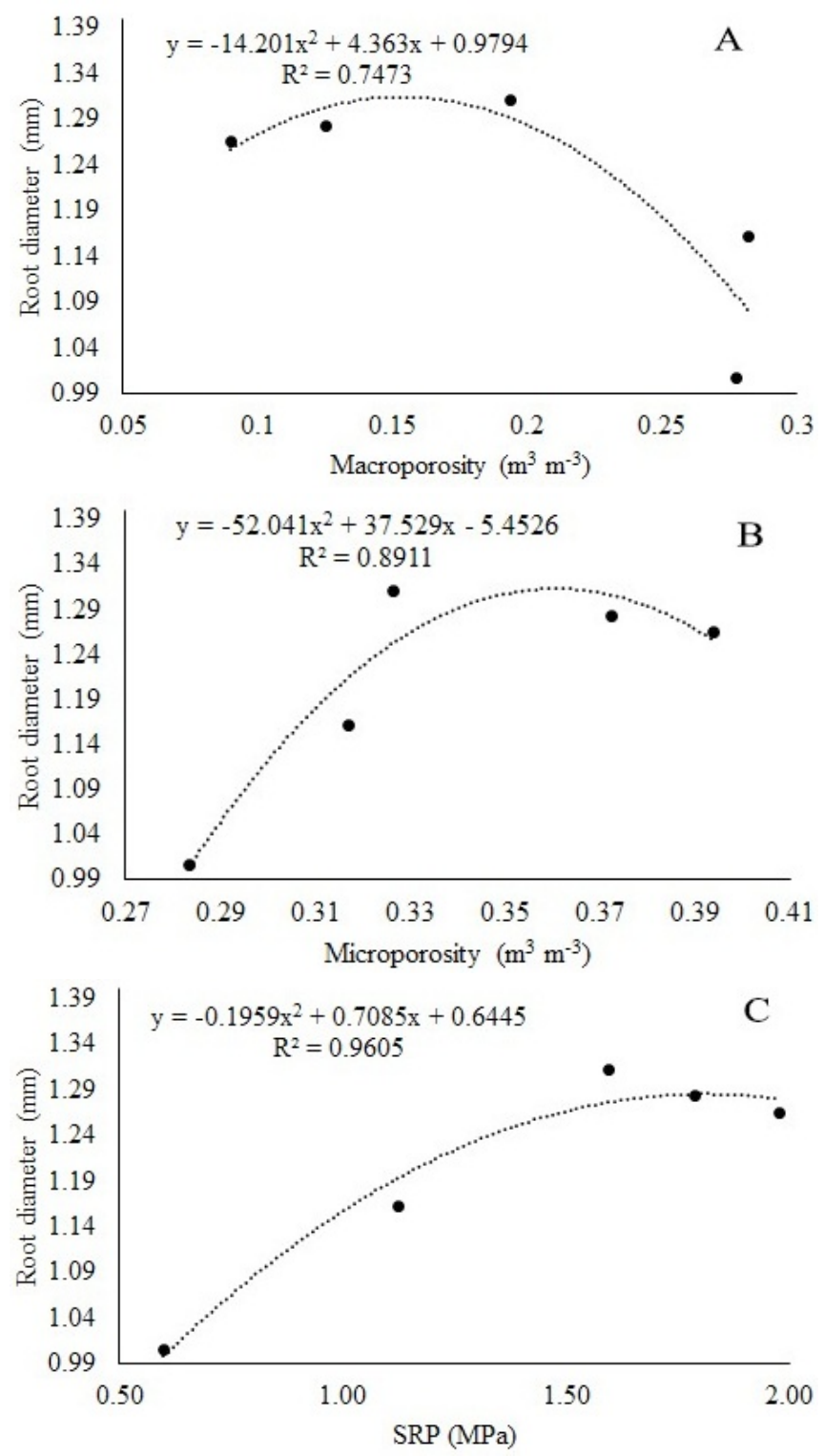

** Significant by the $\mathrm{F}$ test $(\mathrm{p}<0.01)$.

Figure 8. Correlation of the soil physical properties (macroporosity $[A]$, microporosity $[B]$, soil resistance to penetration $[\mathrm{C}]$ ) and the root diameter of the cotton crop.
Based on the models, it was possible to determine the critical indexes for macroporosity, microporosity, and SRP on root growth and yield. For root growth, the values were 0.15 $\mathrm{m}^{3} \mathrm{~m}^{-3}, 0.36 \mathrm{~m}^{3} \mathrm{~m}^{-3}$ and $1.80 \mathrm{MPa}$, respectively. For yield, the values were $0.26 \mathrm{~m}^{3} \mathrm{~m}^{-3}, 0.27 \mathrm{~m}^{3} \mathrm{~m}^{-3}$ and SRP of $0.90 \mathrm{MPa}$. Density and total porosity showed linear behavior, meaning that within the tested range, the higher the density was, the lower total porosity would be, resulting in less yield.

When analyzing the results, it is possible to state that SRP is one of the best indicators of the soil condition in which the plant is subjected, but only if at the collection time there is
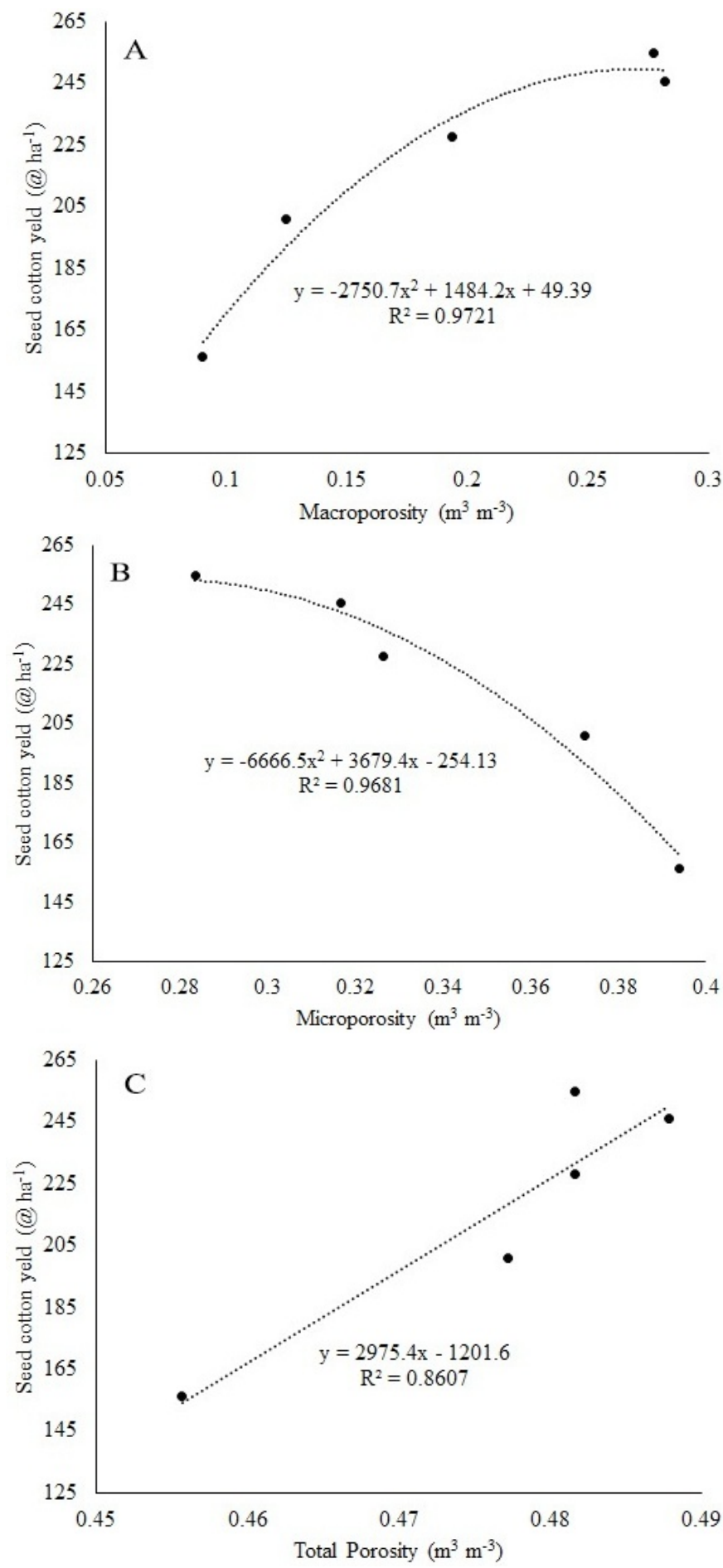

Continues on the next page 
Continued from Figure 9
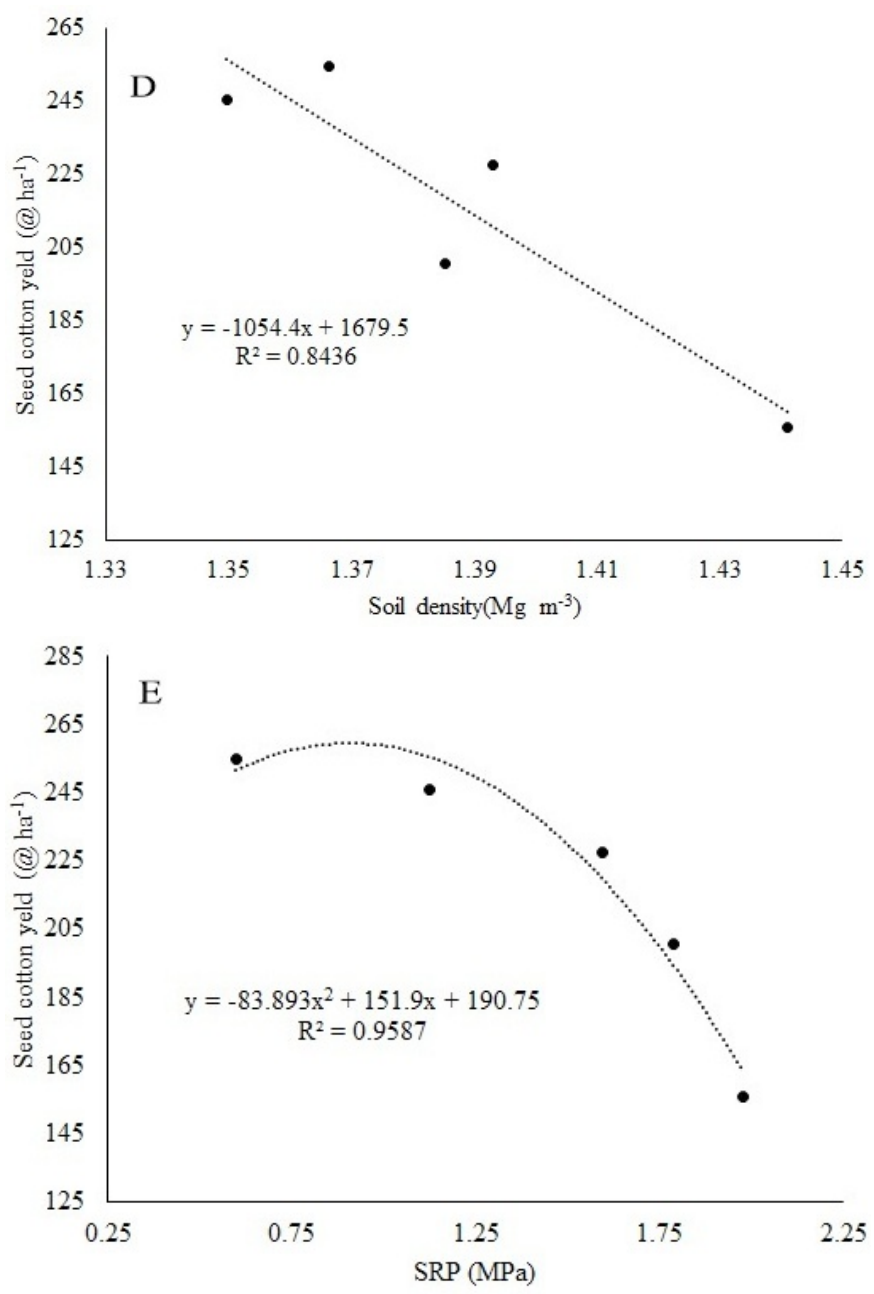

** Significant by the $\mathrm{F}$ test $(\mathrm{p}<0.01)$.

Figure 9. Correlation of soil physical properties (macroporosity $[A]$, microporosity $[B]$, total porosity $[C]$, density $[D]$ and soil resistance to penetration $[E]$ ) and seed cotton yield (PR).

no interference from other factors, such as soil moisture. It is noteworthy that, in general, the values obtained are different from the values commonly found in the literature, however, they were similar to what Scapinelli et al. (2016) found when working on the same soil with the sunflower crop. In the study developed by Freddi et al. (2007), there was a reduction in corn yield from $1.65 \mathrm{MPa}$ onwards. On the other hand, Beutler \& Centurion (2004) verified a decrease in soybean yield from $0.84 \mathrm{MPa}$ on.

\section{Conclusions}

The critical limits for root development were macroporosity, microporosity and soil resistance to penetration, of $0.15 \mathrm{~m}^{3}$ $\mathrm{m}^{-3}, 0.36 \mathrm{~m}^{3} \mathrm{~m}^{-3}$ and $1.80 \mathrm{MPa}$, respectively.

Yield was reduced in the critical values of macroporosity, microporosity and SRP of $0.26 \mathrm{~m}^{3} \mathrm{~m}^{-3}, 0.27 \mathrm{~m}^{3} \mathrm{~m}^{-3}$ and SRP $0.90 \mathrm{MPa}$, respectively.

Soil compaction changes the secondary roots availability and diverts the main radial growth, with a decrease in the explored volume and an increase in the root diameter, up to $10 \mathrm{~cm}$ deep, reflecting a decrease of up to $39 \%$ in yield.

\section{Acknowlodgements}

To the Foundation for Research Support of the State of Mato Grosso - FAPEMAT for financing the study.

\section{Literature Cited}

Andreola, F.; Costa, L.M.; Olszevski. N. Influência da cobertura vegetal de inverno e da adubação orgânica e, ou, mineral sobre as propriedades físicas de uma terra roxa estruturada. Revista Brasileira de Ciência do Solo, v.24, n.4, p.857-865, 2000. https:// doi.org/10.1590/S0100-06832000000400017.

Bengough, A.G.; McKenzie, B.M.; Hallett, P.D.; Valentine, T.A. Root elongation, water stress, and mechanical impedance: a review of limiting stresses and beneficial root tip. Journal of Experimental Botany, v.62, n.1, p.59-68, 2011. https://doi.org/10.1093/jxb/ erq350.

Beutler, N.A.; Centurion, J.F. Compactação do solo no desenvolvimento radicular e na produtividade da soja. Pesquisa Agropecuária Brasileira, v.39, n.6, p.581-588, 2004. https://doi.org/10.1590/ S0100-204X2004000600010

Beutler, N.A.; Centurion, J.F.; Roque, C.G; Ferraz, M.V. Densidade relativa ótima de Latossolos Vermelhos para a produtividade de soja. Revista Brasileira de Ciência do Solo, v.29, n.6, p.843-849, 2005. https://doi.org/10.1590/S0100-06832005000600002.

Ferreira, D.F. Sisvar: um sistema computacional de análise estatística. Ciência e Agrotecnologia, v.35, n.6, p.1039-1042, 2011. https:// doi.org/10.1590/S1413-70542011000600001.

Ferreira, J.C.V. Mato Grosso e seus municípios. Cuiabá: Editora Buriti, 2001. 660p.

Ferreira, R.R.M.; Tavares Filho, J.; Ferreira, V.M. Efeitos de Sistemas de Manejo de Pastagens nas Propriedades Físicas do Solo. Semina: Ciências Agrárias, v.31, n.4, p.913-932, 2010. https://doi. org/10.5433/1679-0359.2010v31n4p913.

Freddi, O.S; Centurion, J.F.; Beutler, A.N; Aratani, R.G.; Leonel, C.L. Compactação do solo no crescimento radicular e produtividade da cultura do milho. Revista Brasileira de Ciência do Solo, v.31, n.4, p.627-636, 2007. https://doi.org/10.1590/S010006832007000400003.

Gomes, R.L.R; Silva, M.C.; Costa, F.; Lima Junior, A.F.; Oliveira, I.P.; Silva, D.B.; Propriedades físicas e teor de matéria orgânica do solo sob diferentes coberturas vegetais. Revista Faculdade Montes Belo, v.8, n.5, p.74-139, 2015 http://revista.fmb.edu.br/ index.php/fmb/article/view/167. 23 Nov. 2019.

lijima, M.; Kato, J.; Taniguchi, A. Combined soil physical stress of soil drying, anaerobiosis and mechanical impedance to seedling root growth of four crop species. Plant Production Science, v.10, n.4, p.451-459, 2007. https://doi.org/10.1626/pps.10.451.

Lima, C.L.R. Compressibilidade de solos versus intensidade de tráfego em um pomar de laranja e pisoteio animal em pastagem irrigada. Piracicaba: Universidade de São Paulo; 2004. 60p. Tese Doutorado. https://teses.usp.br/teses/disponiveis/11/11140/ tde-24052004-160909/publico/claudia.pdf. 18 Fev. 2018. 
Malavolta, E. Manual de nutrição mineral de plantas. São Paulo: Editora Agronômica Ceres, 2006. 631p.

Miguel, P.; Dalmolin, R.S.D.; Zalamena. J.; Medeiros,P.S.C.; Fink, J.R.; Rosa, A.S. Efeitos de diferentes usos do solo na microporosidade e macroporosidade do solo. In: Congresso Brasileiro de Ciência do Solo, 31., Gramado. Anais... Gramado: SBCS, 20007. https:// www.researchgate.net/publication/265403689. 18 Fev. 2018.

Müller, M.M.L.; Ceccon, G.; Rosolem, C.A. Influência da compactação do solo em subsuperfície sobre o crescimento aéreo e radicular de plantas de adubação verde de inverno. Revista Brasileira de Ciência do Solo, v.25, n.3, p.531-538, 2011. https://doi. org/10.1590/S0100-06832001000300002.

Pacheco, L.P; Miguel, A.S.D.C.S.; Silva, E.M.B.; Souza, E.D.; Silva, F.D. Influência da densidade do solo em atributos da parte aérea e sistema radicular de crotalária. Pesquisa Agropecuária Tropical, v.45, n.4, p.464-472, 2015. https://doi.org/10.1590/1983$40632015 \mathrm{v} 4538107$.

Pellegrini, A.; Meinerz, G.R.; Kaiser, D.R. Compactação do solo em sistemas intensivos de integração lavoura-pecuária leiteira. In: Tiecher, T. (Org.). Manejo e conservação do solo e da água em pequenas propriedades rurais no sul do Brasil: práticas alternativas de manejo visando a conservação do solo e da água. Porto Alegre: UFRGS, 2016. p.49-64. https://lume.ufrgs.br/ handle/10183/149123. 18 Fev. 2018.

Pessoa, U.C.M.; Silva Terceiro, E.N, Souza, A.S; Soares Filho, A.A, Pimenta TA. Interferência de tiririca (Cyperus rotundus L.) e da compactação do solo no crescimento do feijão-caupi. Revista Verde, v.10, n.5, p.61-69, 2015. https://doi.org/10.18378/rvads. v10i5.4068.
Rossetti, K.V.; Centurion, J.F. Indicadores de qualidade em Latossolos compactados e suas relações com o crescimento do sistema radicular do milho. Revista Agro@mbiente on-line, v.11, n.3, p.181190, 2017. https://doi.org/10.18227/1982-8470ragro.v11i3.3845.

Santos, H.G. dos; Jacomine, P.K.T.; Anjos, L.H.C. dos; Oliveira, V.A. de; Lumbreras, J.F.; Coelho, M.R.; Almeida, J.A. de; Araújo Filho, J.C. de; Oliveira, J. B. de; Cunha, T. J. F. Sistema brasileiro de classificação de solos. 5.ed. Brasília: Embrapa, 2018. 356p.

Scapinelli, A, Deina, D.R.; Valadão Junior, D.D.V.; Valadão, F.C.A.; Pereira, L.B. Sistema radicular e componentes produtivos do girassol em solo compactado. Bragantia, v.75, n.4, p.474-486, 2016. https://doi.org/10.1590/1678-4499.286.

Stefanoski, D.C; Santos, G.G.; Marchão, R.L.; Petter, F.A; Pacheco, L.P. Uso e manejo do solo e seus impactos sobre a qualidade física. Revista Brasileira de Engenharia Agrícola e Ambiental, v.17, n.12, p.13011309, 2013. https://doi.org/10.1590/S1415-43662013001200008.

Teixeira, P.C.; Donagemma, G.K.; Fontana, A.; Teixeira, W.G. (Eds.). Manual de métodos de análise de solo. 3.ed. Brasília: Embrapa, 2017. 573 p.

Valadão, F.C.A.; Weber, O.L.S.; Valadão Junior, D.D.; Santin, M.F.M.; Scapinelli, A. Teor de macronutrientes e produtividade da soja influenciados pela compactação do solo e adubação fosfatada. Revista de Ciências Agrarias, v.40, n.1, p.183-195, 2017. https:// doi.org/10.19084/RCA15092.

Valadão, F.C.A.; Weber, O.L.S.; Valadão Júnior, D.D.; Scapinelli, A.; Deina, F.R.; Bianchini, A. Adubação fosfatada e compactação do solo: sistema radicular da soja e do milho e atributos físicos do solo. Revista Brasileira de Ciência do Solo, v.39, n.1, p.243-255, 2015. https://doi.org/10.1590/01000683rbcs20150144. 